\title{
Inhalt, Vol. 9, No. 3, 1986
}

\section{Contents}

Impressum 132

Editorial $\quad 134$

Link, H., Hannover, Frauer, H. M.; Waller, H.D.; Ostendorf, P. und Wilms, K., Tubingen,

Kurrle, E.; Heil, G.; Heimpel, H. und Hoelzer, D., Ulm

TAD-Induktionstherapie bei 175 Erwachsenen mit akuter mye-

loischer Leukämie mit anschließender Konsolidations- und

Erhaltungstherapie. Ergebnisse der gemeinsamen Studie von

Ulm und Tubingen* 135

Kurrle, E. und Heil, G., Ulm, Ehninger, G., Tubingen,

Freund, M. und Link, H., Hannover, Hoelzer, D. und

Mitrou, P. S., Frankfurt

Altersadaptierte Induktions- und intensivierte Konsolidations-

therapie bei akuter myeloischer Leukämie* 141

Hiddemann, W. und Büchner, Th., Münster, Kreutzmann, H.,

Essen-Werden, Straif, K., Bonn, Ludwig, W. D., Berlin,

Dornhuijsen-Ant, R., Duisburg-Hamborn, Lengfelder, E.,

Mannheim-Heidelberg und Arlin, Z., New York/USA

Hoch-Dosis Cytosin-Arabinosid und Mitoxantrone bei refraktä-

rer akuter myeloischer Leukämie: eine klinische Phase-I/II-

Studie*

144

Ho, A. D. und Körbling, M., Heidelberg, Lipp, Th. und

Kaboth, W., München-Schwabing, Ehninger, G. und Steinke, B.,

Tubingen, Meyer, P. und Ruckle, H., Würzburg

Therapie der refraktären akut-myeloischen Leukämien mit

MitoxantronundVP-16* 148

Hinweise für Autoren 150

Fülle, H. H. und Hellriegel, K. P. , Berlin

Idarubicin bei refraktärer akuter Leukämie* 152

Fink, F. M.; Grünmayer, E. R. und Gadner, H., Wien/Österreich, Kardos, G., Revesz, T. und Schuler, D., Budapest/Ungarn

Aclacinomycin-A in der Induktionstherapie von AML bei Kin-

dern* 154

Neuigkeiten für die klinische Praxis 156

Deutsche Morbus Hodgkin Studiengruppe

Zwischenergebnisse der Deutschen Morbus Hodgkin-Therapie-

studie* 159 
Ganser, A.; Brücher, W.; Brodt, H. R.; Busch, W.;

Brandhorst, I.; Heim, E. B. und Hoelzer, D. , Frankfurt

Therapie des AIDS-assoziierten Kaposi-Sarkoms mit rekombi-

nantem GammaTnterferon* 163

Peest et ah, Deutsche Myeloma Studiengruppe,

Med. Hochschule Hannover

Aktuelle Ergebnisse einer multizentrischen Studie beim multip-

len Myelom* 168

Sonderbände 169

Buchbesprechungen 170

Schuster, D.; Heim, M. E.; Andres, R. und Queißer, W.,

Mannheim

Lebensqualität von Karzinom-Patienten unter Chemo- und

Radiotherapie 172

* Aktuelle Therapiestudien: vorgetragen anläßlich der Gemeinsamen Jahrestagung der Österreichischen und Deutschen Gesellschaft für Hämatologie und Onkologie, Wien 1985

Zusammengestellt von: K. P. Hellriegel, 2. Innere Klinik, Kranken-haus Moabit. Berlin

Imprint 132

Editorial $\quad 134$

Link, H., Hannover, Frauer, H. M.; Waller, H.D.; Ostendorf, P. and Wilms, K., Tubingen,

Kurrle, E.; Heil, G.; Heimpel, H. and Hoelzer, D., Ulm

TAD Induction Therapy for 175 Adults with Acute Myeloid

Leukemia, Followed by Consolidation and Maintenance

Therapy. The Joint Study of Ulm and Tubingen* 135

Kurrle, E. and Heil, G., Ulm, Ehninger, G., Tubingen,

Freund, M. and Link, H., Hanover, Hoelzer, D. and

Mitrou, P. S., Frankfurt

Age Adapted Induction and Intensified Consolidation Therapy

in Acute Myelogenous Leukemia* 141

Hiddemann, W. and Büchner, Th., Münster, Kreutzmann, H., Essen-Werden, Straif, K., Bonn, Ludwig, W. D., Berlin, Dornhuijsen-Ant, R., Duisburg-Hamborn, Lengfelder, E., MannheimHeidelberg and Arlin, Z., New YorklU.S.A. High-Dose Cytosine-Arabinoside and Mitoxantrone in Refractory Acute Myeloid Leukemia: A Clinical Phase I/II-Study* . . 144

Ho, A. D. and Körbling, M., Heidelberg, Lipp, Th. and

Kaboth, W., Munich-Schwabing, Ehninger, G. and Steinke, B.,

Tubingen, Meyer, P. and Ruckle, H., Würzburg

Mitoxantrone and VP-16 in Refractory Acute Myelogenous

Leukemia* 148

Instructions for Authors 150

Fülle, H. H. and Hellriegel, K. P., Berlin

Idarubicin in Refractory Acute Leukemia* 152

Fink, F. M.; Grünmayer, E. R. and Gadner, H., Vienna!Austria,

Kardos, G., Revesz, T. and Schuler, D., Budapest! Hungary

Aclacinomycin-A in the Induction Treatment of Childhood

AML* 154

News for Clinical Practice 156 
German Hodgkin Study Group

Preliminary Results of the German Hodgkin Study* 159

Ganser, A.; Brücher, W.; Brodt, H. R.; Busch, W.;

Brandhorst, I.; Heim, E. B. and Hoelzer, D., Frankfurt

Treatment of AIDS-Related Kaposi's Sarcoma with Recombi-

nant $\gamma$-Interferon* 163

Peest etal., Deutsche Myeloma Studiengruppe,

Med. Hochschule Hannover

Current Results of a Multicenter Trial in Multiple Myeloma*

168

Special Editions

169

Book Reviews 170

Schuster, D.; Heim, M. E.; Andres, R. and Queißer, W., Mannheim

Quality of Life of Cancer Patients Receiving Chemo- and Radio

therapy $\quad 172$

* Current Therapy Studies have been presented in the Gcmeinsamc Jahrestagung der Österreichischen und Deutschen Gesellschaft für Hämatologie und Onkologie in Vienna, October 1985 Compiled by K. P. Hellriegel, 2. Innere Klinik, Krankenhaus Moabit, Berlin Bibliographischer Hinweis: Inhaltsverzeichmsse dieser Zeitschrift erscheinen regelmäßig in current contents ${ }^{\circledR}$ sowie in anderen bibliographischen Diensten. 